\title{
Hubungan antara Waktu Tunggu Pelayanan Resep dengan Tingkat Kepuasan Pasien Rawat Jalan BPJS terhadap Pelayanan Resep (Penelitian dilakukan di Instalasi Farmasi Rumah Sakit Universitas Muhammadiyah Malang)
}

\author{
Muhammad Ihsan*, Ratna Kurnia Illahi, Hananditia Rachma Pramestutie \\ Jurusan Farmasi, Fakultas Kedokteran, Universitas Brawijaya, Malang, Indonesia
}

\begin{abstract}
INFO ARTIKEL
Sejarah artikel:

Penerimaan naskah: 2

Januari 2018

Penerimaan naskah

revisi: 23 Juni 2018

Disetujui untuk

dipublikasikan: 26

Juni 2018

\section{Kata kunci :}

Waktu Tunggu,

Kepuasan Pasien,

Pelayanan Resep,

Instalasi Farmasi

Rumah Sakit

\section{A B S T R A K}

Pelayanan kefarmasian di Instalasi Farmasi Rumah Sakit merupakan salah satu unit pelayanan yang wajib disediakan rumah sakit. Terdapat beberapa indikator yang harus dipenuhi oleh Instalasi Farmasi Rumah Sakit, salah satunya adalah kepuasan pasien dan waktu tunggu pelayanan resep, yang dianggap dapat mempengaruhi ekspektasi pasien terhadap pelayanan rumah sakit, khususnya pelayanan di Instalasi Farmasi Rumah Sakit. Penelitian ini bertujuan untuk mengetahui hubungan antara waktu tunggu pelayanan resep dengan tingkat kepuasan pasien pada pelayanan resep di Instalasi Farmasi Rumah Sakit, dengan pendekatan observasional analitis pada 150 orang pasien rawat jalan BPJS atau pengantarnya yang sedang menebus resep. Kuesioner dan stopwatch masing-masing digunakan sebagai instrumen untuk mengukur kepuasan pasien dan waktu tunggu pelayanan resep. Analisis data dilakukan dengan 2 metode, yaitu metode Pearson untuk pelayanan resep obat racikan dan Spearman untuk pelayanan resep obat jadi. Dari penelitian ini, terdapat hubungan antara waktu tunggu pelayanan resep dengan tingkat kepuasan pasien pada pelayanan resep obat jadi $(\mathrm{p}=0,049)$, tetapi tidak terdapat hubungan antara kedua variabel pada pelayanan resep obat racikan $(\mathrm{p}=0,516)$. Selain itu, didapatkan rata-rata waktu tunggu pelayanan resep sekitar 39 menit 34 detik untuk pelayanan resep obat racikan dan 29 menit 0 detik untuk pelayanan resep obat jadi. Berdasarkan perundangan, waktu tunggu pelayanan resep yang ditentukan adalah tidak lebih dari 30 menit untuk pelayanan resep obat jadi dan 60 menit untuk pelayanan resep obat racik. Dari hasil penelitian tersebut dapat disimpulkan bahwa terdapat hubungan antara waktu tunggu pelayanan resep dengan tingkat kepuasan pasien, dan waktu tunggu pelayanan resep pada penelitian ini telah sesuai dengan peraturan perundangan yang ditetapkan.
\end{abstract}

\section{The Correlation between Prescription Service Waiting Time and BPJS Insurance Outpatients Satisfaction Rate at Universitas Muhammadiyah Hospital Malang}

\section{Keywords:}

Waiting Time, Patient

Satisfaction,

Prescription Service, Pharmacy Service

\begin{abstract}
A B S T R A C T
Pharmacy service is one of services that should be provided at hospital. Some indicators should be fulfilled by pharmacy service, including patient satisfaction and prescription service waiting time. These indicators could influence patient expectation towards hospital services, especially pharmacy service. This study aims to determine the relationship between prescription service waiting time and patient satisfaction rate, with analytic observational angle on 150 outpatients with JKN insurance. Instruments used on this study were questionnaire to measure patient satisfaction and stopwatch to measure prescription waiting time. Data analysis were conducted using Pearson test for mixed drug prescription service and Spearman test for receipt drug prescription service. The result from this study showed that there was relationship between waiting time and patient satisfaction rate on receipt drug prescription service $(p=0,049)$, but there was no relationship between two variables on mixed drug prescription service $(p=0,049)$. Furthermore, average waiting time obtained were 39 minutes 34 seconds on concoction drug prescription service and 29 minutes 0 seconds on non-concoction drug prescription service. According to regulation, waiting time determined were no more than 30 minutes for receipt drug prescription service and 60 minutes for mixed drug prescription service. From this study, there was relationship between prescription service waiting time and patient satisfaction rate, and prescription service waiting time on this study was suitable with regulation.
\end{abstract}




\section{Pendahuluan}

Instalasi Farmasi merupakan salah satu pelayanan fungsional yang dilakukan oleh apoteker dengan menyelenggarakan kegiatan kefarmasian di rumah sakit, yang meliputi perencanaan, pengadaan, produksi, penyimpanan, dispensing, pengendalian mutu, serta penggunaan sediaan farmasi, bahan medis habis pakai, maupun alat kesehatan di rumah sakit. ${ }^{1,2}$ Kehadiran Instalasi Farmasi Rumah Sakit penting bagi keberlangsungan rumah sakit, karena sifatnya fungsional. Hal ini didukung oleh Standar Pelayanan Minimal Rumah Sakit (SPM RS), di mana Instalasi Farmasi Rumah Sakit (IFRS) merupakan salah satu jenis pelayanan yang wajib disediakan di rumah sakit. ${ }^{3}$ Mengacu pada regulasi tersebut, maka untuk sebuah Instalasi Farmasi yang terdapat di rumah sakit harus memenuhi beberapa indikator, salah satunya adalah tingkat kepuasan pasien (standar minimal 80\%) dan waktu tunggu pelayanan resep (maksimal 30 menit untuk obat jadi dan 60 menit untuk obat racik). ${ }^{3}$

Dari standar tersebut, akan didapatkan tingkat efisiensi, efektivitas serta kesinambungan pelayanan IFRS melalui waktu tunggu pelayanan resep $^{3}$, serta tingkat kenyamanan dan gambaran persepsi pelayanan IFRS melalui kepuasan pasien. ${ }^{3}$ Waktu tunggu pelayanan resep mempengaruhi ekspektasi pasien terhadap pelayanan rumah sakit, khususnya pada pelayanan IFRS. Jika pasien merasa tidak puas dengan pelayanan yang diberikan, maka pasien sebagai konsumen pun akan enggan berkunjung kembali ke rumah sakit, sehingga dapat mempengaruhi angka kunjungan rumah sakit. Selain itu, karena tingkat kepuasan pasien berkaitan erat dengan luaran dari hasil pelayanan kepada pasien, yaitu cara penggunaan obat, maka akan muncul reaksi yang tidak diinginkan dan penurunan kualitas hidup pasien akibat cara penggunaan obat yang tidak benar. ${ }^{4}$ Hal tersebut dapat muncul akibat pasien merasa enggan untuk mengikuti instruksi yang diberikan oleh petugas farmasi. ${ }^{4}$

Sebagai salah satu rumah sakit yang terdapat di kota Malang, Rumah Sakit Universitas Muhammadiyah Malang menjadi salah satu tujuan pengobatan bagi masyarakat sekitarnya. Terdapat beberapa rujukan dan pelayanan yang dilakukan di rumah sakit tersebut, yang salah satunya adalah pelayanan resep pasien yang memiliki keanggotaan Badan Penyelenggaraan Jaminan Sosial (BPJS). BPJS merupakan salah satu bentuk perlindungan sosial yang terpadu dan menyeluruh bagi seluruh masyarakat ${ }^{11}$. Karena pelayanan kesehatan yang diberikan bersifat menyeluruh, maka peserta BPJS secara otomatis juga mendapatkan pelayanan farmasi, termasuk pelayanan kefarmasian di rumah sakit. Dari hal tersebut, maka akan semakin banyak masyarakat yang berkunjung ke pelayanan IFRS, yang menyebabkan meningkatnya tuntutan terhadap pelayanan kefarmasian di rumah sakit untuk meningkatkan kualitas pelayanannya setiap waktu.

Penurunan angka kunjungan rumah sakit salah satunya dapat terjadi jika pelayanan IFRS yang dilakukan buruk. Hal ini didasarkan oleh penelitian yang dilakukan oleh Megawati di Rumah Sakit Baptis Batu, di mana dari hasil survei yang dilakukan sebelumnya, pelayanan IFRS merupakan 1 dari 3 pelayanan terburuk yang dirasakan oleh pasien. ${ }^{6}$ Dari data survei lanjutan yang dilakukan pada penelitian tersebut, diketahui bahwa waktu tunggu pelayanan obat merupakan indikator ketidakpuasan terbesar yang terjadi di unit IFRS pada pasien rawat jalan. ${ }^{6}$ Melalui data sekunder Rumah Sakit Baptis Batu, diketahui terjadi penurunan jumlah kunjungan pasien rawat jalan sebanyak 400-500 pasien per bulan selama semester I tahun 2014 (dibandingkan tahun 2013). ${ }^{6}$ Karena unit IFRS merupakan unit yang memberikan pendapatan terbesar ketiga di Rumah Sakit Baptis Batu (setelah Kamar Operasi dan Rawat Inap), maka penurunan jumlah kunjungan pasien rawat jalan juga ikut menurunkan pendapatan Rumah Sakit pada penelitian tersebut. $^{6}$

Data terkait waktu tunggu pelayanan resep dan tingkat kepuasan pasien di rumah sakit belum banyak terdokumentasikan, sehingga memberikan peluang untuk melakukan penelitian terkait hal tersebut. Penelitian ini bertujuan untuk mengetahui hubungan antara waktu tunggu pelayanan resep dengan tingkat kepuasan pasien rawat jalan BPJS pada pelayanan resep, sehingga diharapkan dapat menjadi salah satu acuan dan umpan balik bagi Instalasi Farmasi Rumah Sakit Rumah Sakit Universitas Muhammadiyah Malang untuk memperbaiki kualitas pelayanannya.

\section{Metode}

Penelitian ini merupakan penelitian observasional analitis dengan pendekatan cross-sectional, di mana akan diketahui hubungan antar variabel melalui data yang didapatkan dengan pengamatan secara langsung. Studi dilakukan di IFRS Rumah Sakit Universitas Muhammadiyah pada bagian rawat jalan, dimulai dari bulan Agustus - Oktober 2017. Instrumen yang digunakan masing-masing berupa stopwatch untuk mengukur waktu tunggu pelayanan resep dan kuesioner model SERVQUAL berskala Likert untuk mengukur tingkat kepuasan pasien. Pada penelitian ini, penilaian terhadap kepuasan pelayanan IFRS terbagi atas 4 macam, yaitu Sangat Tidak Puas, Tidak Puas, Puas, dan Sangat Puas. Pengambilan data dilakukan mulai saat pasien menyerahkan resep ke loket penyerahan resep hingga saat konseling selesai dilakukan menggunakan stopwatch, kemudian dilanjutkan dengan pemberian kuesioner kepada pasien untuk dilakukan pengisian. Data pendukung juga didapatkan melalui wawancara dengan sebagian responden dan petugas farmasi di IFRS. Penelitian ini juga telah memenuhi kelayakan etik dari Komisi Etik Penelitian Kesehatan Fakultas Kedokteran Universitas Brawijaya No. 263/EC/KEPK-S1-FARM/07/2017.

\section{- Uji Validitas dan Reliabilitas}

Sebelum kuesioner digunakan sebagai instrumen penelitian untuk mengukur tingkat kepuasan pasien, uji validitas dan reliabilitas kuesioner perlu dilakukan terlebih dahulu. Kedua uji dilakukan pada 30 sampel di lokasi studi yang sama, tetapi sampel tersebut tidak termasuk dalam sampel penelitian sebenarnya. Pengujian selanjutnya 
dilakukan dengan menggunakan IBM SPSS 21, di mana kuesioner dinyatakan valid jika probabilitas korelasi [sig.2(tailed)] didapatkan $\leq 0.05$ dan reliabel jika koefisien korelasi Chronbach's alpha $(\alpha) \geq 0.05$.

\section{- Sampel}

Pada penelitian ini, sampel yang diambil adalah pasien rawat jalan BPJS atau pengantarnya yang sedang menebus resep di IFRS Rumah Sakit Universitas Muhammadiyah Malang. Pemilihan sampel dilakukan menggunakan purposive sampling, yang selanjutnya akan disesuaikan dengan kriteria inklusi dan eksklusi, dan sampel sebanyak minimal 100 orang menggunakan rumus Lemmeshow.

\section{- Kriteria Inklusi}

Responden rawat jalan dan/atau pengantarnya yang sedang menebus resep di IFRS Rumah Sakit Universitas Muhammadiyah Malang, memiliki resep yang berasal dari poli Rumah Sakit Universitas Muhammadiyah Malang, memiliki keanggotaan JKN - BPJS, bersedia menandatangani informed consent, dapat menerima informasi dari kuesioner atau wawancara yang diberikan (baik secara lisan maupun tulisan), serta berusia $\geq 20$ tahun.

\section{- Kriteria Eksklusi}

Responden yang membawa resep berisi lebih dari 5 item obat untuk ditebus, serta membawa resep yang berasal dari lebih dari 1 poli di IFRS Rumah Sakit Universitas Muhammadiyah Malang, dan responden yang dalam 1 lembar resep terdapat obat racik dan jadi pada saat yang sama.

\section{- Analisis Data}

Pada penelitian ini, data secara keseluruhan data terbagi menjadi 2 macam, yaitu untuk pelayanan resep obat jadi dan obat racik. Analisis data deskriptif dilakukan untuk masing-masing data waktu tunggu pelayanan resep dan kepuasan pasien. Pada data waktu tunggu pelayanan resep, data terbagi menjadi beberapa kategori, yaitu lebih dan kurang dari 30 menit untuk pelayanan resep obat jadi serta lebih dan kurang dari 60 menit untuk pelayanan resep obat racik Sedangkan pada data kepuasan pasien, data terbagi sesuai dengan skala Likert yang digunakan, yaitu sangat tidak puas, tidak puas, puas, dan sangat puas.

Setelah itu, dilakukan uji distribusi data menggunakan metode Kolmogorov-Smirnov, yang selanjutnya dilakukan menggunakan metode Pearson atau Spearman sebagai analisis korelasional, yang masingmasing dilakukan menggunakan IBM SPSS 21. Pengambilan hipotesis didasarkan pada tingkat signifikansi, di mana jika nilai sig $<0.05$, maka terdapat hubungan yang signifikan antara waktu tunggu pelayanan resep dengan tingkat kepuasan pasien.

\section{Hasil}

Pada penelitian ini, didapatkan jumlah responden sebanyak 150 orang, yaitu 141 orang dengan resep yang berisi obat jadi dan 9 orang yang mendapatkan resep berisi obat racik. Pada Tabel 1, sebagian besar responden merupakan wanita yang berusia $20-29$ tahun, berprofesi sebagai ibu rumah tangga, memiliki tingkat pendidikan tinggi, dan sebelumnya pernah mengunjungi fasilitas IFRS sebanyak lebih dari 5 kali.

Tabel 1. Karakteristik Responden mengenai Jenis Kelamin, Usia, dan Tingkat Pendidikan

\begin{tabular}{|c|c|c|c|}
\hline Parameter & Kategori & $\begin{array}{l}\text { Jumlah } \\
\text { (Orang) }\end{array}$ & $\begin{array}{c}\text { Persentase } \\
(\%)\end{array}$ \\
\hline \multirow[t]{2}{*}{ Jenis Kelamin } & Pria & 31 & 20,67 \\
\hline & Wanita & 110 & 73,33 \\
\hline \multirow[t]{4}{*}{ Usia } & $20-29$ tahun & 68 & 45,33 \\
\hline & $30-39$ tahun & 34 & 22,67 \\
\hline & $40-49$ tahun & 21 & 14,00 \\
\hline & $>50$ tahun & 18 & 12,00 \\
\hline \multirow{3}{*}{$\begin{array}{c}\text { Tingkat } \\
\text { Pendidikan }\end{array}$} & Dasar & 11 & 7,33 \\
\hline & Menengah & 44 & 29,33 \\
\hline & Tinggi & 86 & 57,34 \\
\hline \multirow[t]{8}{*}{ Jenis Pekerjaan } & Mahasiswa / & 26 & 17,33 \\
\hline & Pelajar & & \\
\hline & Wiraswasta & 13 & 8,67 \\
\hline & Pegawai Negeri & 12 & 8,00 \\
\hline & Pegawai Swasta & 33 & 22,00 \\
\hline & Ibu Rumah & 43 & 28,67 \\
\hline & Tangga & & \\
\hline & Lain-lain & 14 & 9,33 \\
\hline Jumlah & Pertama kali & 23 & 15,33 \\
\hline \multicolumn{4}{|l|}{ Kunjungan } \\
\hline & $2-5$ kali & 46 & 30,67 \\
\hline & $>5$ kali & 72 & 48,00 \\
\hline
\end{tabular}

Berdasarkan hasil perhitungan nilai Likert, secara umum responden sebagian besar merasa sangat puas terhadap pelayanan resep yang diberikan oleh petugas farmasi. Hasil dapat dilihat pada Gambar 1.

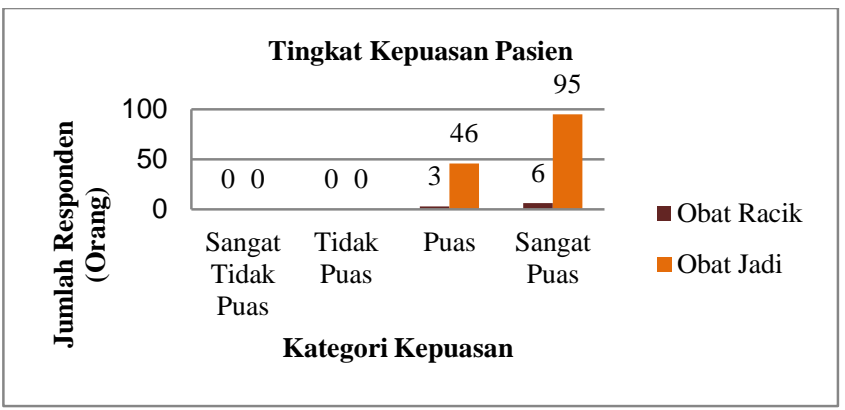




\begin{tabular}{|c|c|c|c|c|}
\hline \multirow[t]{2}{*}{ No } & \multirow[t]{2}{*}{ Aspek } & \multicolumn{2}{|c|}{ Jumlah (Orang) } & \multirow{2}{*}{$\begin{array}{c}\text { Total } \\
\text { (Orang) }\end{array}$} \\
\hline & & $\begin{array}{l}\text { Tidak } \\
\text { Puas }\end{array}$ & $\begin{array}{c}\text { Sangat } \\
\text { Tidak } \\
\text { Puas }\end{array}$ & \\
\hline 1. & $\begin{array}{l}\text { Waktu Tunggu } \\
\text { Pelayanan Resep }\end{array}$ & 36 & 3 & 39 \\
\hline 2. & $\begin{array}{l}\text { Memberikan harapan } \\
\text { agar cepat sembuh }\end{array}$ & 14 & 3 & 17 \\
\hline 3. & $\begin{array}{l}\text { Mengingatkan agar } \\
\text { patuh minum obat }\end{array}$ & 16 & 1 & 17 \\
\hline 4. & $\begin{array}{l}\text { Tanggap terhadap } \\
\text { keluhan / komplain }\end{array}$ & 14 & 1 & 15 \\
\hline 5. & $\begin{array}{c}\text { Kemampuan } \\
\text { memberikan informasi } \\
\text { terkait dengan obat } \\
\text { secara jelas }\end{array}$ & 12 & 0 & 12 \\
\hline 6. & $\begin{array}{c}\text { Dapat memberi solusi } \\
\text { terhadap keluhan / } \\
\text { komplain }\end{array}$ & 10 & 0 & 10 \\
\hline 7. & $\begin{array}{l}\text { Kelengkapan fasilitas } \\
\text { ruang tunggu pelayanan }\end{array}$ & 9 & 0 & 9 \\
\hline 8. & $\begin{array}{l}\text { Keramahan dalam } \\
\text { melayani pasien }\end{array}$ & 5 & 2 & 7 \\
\hline 9. & $\begin{array}{l}\text { Kenyamanan ruang } \\
\text { tunggu pelayanan }\end{array}$ & 7 & 0 & 7 \\
\hline 10. & $\begin{array}{l}\text { Ketersediaan obat di } \\
\text { IFRS }\end{array}$ & 7 & 0 & 7 \\
\hline 11. & $\begin{array}{l}\text { Kesopanan dalam } \\
\text { melayani pasien }\end{array}$ & 7 & 0 & 7 \\
\hline
\end{tabular}

Gambar 1. Tingkat Kepuasan Pasien terhadap Pelayanan Resep

Namun, ketika ditinjau dari nilai Likert dari masing-masing pertanyaan, terdapat sebagian responden yang merasa sangat tidak puas, bahkan tidak puas terhadap pelayanan IFRS di Rumah Sakit Universitas Muhammadiyah Malang. Dari jumlah responden yang tidak puas dan sangat tidak puas terhadap sebagian aspek kepuasan, didapatkan 11 indikator ketidakpuasan terhadap pelayanan IFRS seperti pada Tabel 2. Sedangkan pada waktu tunggu pelayanan resep, sebagian besar responden tidak memerlukan waktu lebih dari 30 menit untuk melakukan pengambilan obat jadi dan tidak lebih dari 60 menit untuk melakukan pengambilan obat racik. Kemudian hasil pengukuran waktu tunggu pelayanan responden dijumlahkan dan dibagi dengan jumlah responden. Data waktu tunggu pelayanan resep dapat dilihat pada Tabel 3 .
Tabel 2. Penyebab Ketidakpuasan Terbesar pada Pelayanan IFRS

Pada penelitian ini, dilakukan uji korelasi antara waktu tunggu pelayanan resep dengan tingkat kepuasan pasien menggunakan 2 metode yang berbeda, yaitu metode Pearson untuk pelayanan resep obat racik dan metode Spearman untuk pelayanan resep obat jadi. Hasil dapat dilihat pada Tabel 4.

Tabel 3. Waktu Tunggu Pelayanan Resep

\begin{tabular}{|c|c|c|c|c|c|}
\hline $\begin{array}{c}\text { Jenis } \\
\text { Pelayanan } \\
\text { Resep }\end{array}$ & $\begin{array}{c}\text { Waktu } \\
\text { Tunggu }\end{array}$ & $\begin{array}{l}\text { Jumlah } \\
\text { (Orang) }\end{array}$ & $(\%)$ & $\begin{array}{c}\text { Jumlah } \\
\text { Waktu } \\
\text { Tunggu } \\
\text { Pelayanan } \\
\text { Resep }\end{array}$ & $\begin{array}{c}\text { Rata-rata } \\
\text { Waktu } \\
\text { Tunggu } \\
\text { Pelayanan } \\
\text { Resep }\end{array}$ \\
\hline Obat Jadi & $\begin{array}{c}<30 \\
\text { menit } \\
>30 \\
\text { menit }\end{array}$ & 60 & 42,55 & $\begin{array}{c}4089 \\
\text { menit } 15 \\
\text { detik }\end{array}$ & $\begin{array}{c}29 \text { menit } 0 \\
\text { detik }\end{array}$ \\
\hline $\begin{array}{l}\text { Obat } \\
\text { Racik }\end{array}$ & $\begin{array}{l}<60 \\
\text { menit }\end{array}$ & 8 & 88,89 & $\begin{array}{l}351 \text { menit } \\
31 \text { detik }\end{array}$ & $\begin{array}{l}39 \text { menit } \\
34 \text { detik }\end{array}$ \\
\hline & $\begin{array}{l}>60 \\
\text { menit }\end{array}$ & 1 & 11,11 & & \\
\hline
\end{tabular}

Tabel 4. Hubungan antara Waktu Tunggu Pelayanan Resep dengan Tingkat Kepuasan Pasien

\begin{tabular}{ccccc}
\hline $\begin{array}{c}\text { Jenis } \\
\text { Pelayanan } \\
\text { Resep }\end{array}$ & $\begin{array}{c}\text { Hasil Uji } \\
\text { Distribusi }\end{array}$ & Metode & $\begin{array}{c}\text { Kekuatan } \\
\text { Korelasi }\end{array}$ & Nilai p \\
\hline Obat Jadi & 0,000 & Spearman & $-0,166$ & 0,049 \\
\hline Obat Racik & 0,825 & Pearson & 0,250 & 0,516 \\
\hline
\end{tabular}

\section{Diskusi}

Berdasarkan hasil penelitian yang tertera pada Tabel 1, didapatkan sebagian besar responden merupakan wanita berusia 20 - 29 tahun, dengan profesi sebagai ibu rumah tangga, memiliki tingkat pendidikan tinggi, dan pernah mengunjungi IFRS sebelumnya sebanyak lebih dari 5 kali. Dari hasil tersebut, secara umum responden memiliki tuntutan yang besar terhadap pelayanan IFRS yang diberikan. Hal ini ditinjau dari usia, tingkat pendidikan, dan jumlah kunjungan ke IFRS. Meskipun melalui data jenis kelamin dan jenis pekerjaan menunjukkan bahwa tuntutan terhadap pelayanan IFRS tidak sebesar 3 data demografi yang lainnya, tetapi responden tetap akan menuntut pelayanan IFRS untuk memberikan pelayanan yang lebih baik setiap waktunya.

Dalam hubungannya dengan kepuasan pasien, usia mempengaruhi tingkat pengetahuan, pola pikir, dan tindakan terhadap pelayanan yang diberikan. Selain itu, 
secara emosional seseorang akan semakin terbuka terhadap hal-hal yang diterima dari lingkungan seiring bertambahnya usia. ${ }^{10}$ Pada penelitian ini, sebagian besar responden berusia 20-29 tahun (45,33\%), di mana responden pada rentang usia tersebut dianggap memiliki tingkat pengetahuan yang relatif tinggi, tetapi secara emosional cenderung belum dapat menerima pelayanan yang diberikan.

Pada penelitian ini, sebagian besar responden memiliki tingkat pendidikan tinggi, yaitu SMA dan Sarjana (57,34\%). Dalam kaitannya dengan tingkat kepuasan, tingkat pendidikan mempengaruhi tingkat pengetahuan terhadap pelayanan yang diberikan. ${ }^{7}$ Hal ini juga akan mempengaruhi kemampuan seorang individu dalam menerima informasi. Berdasarkan pengetahuan akan pelayanan IFRS, maka responden akan memiliki permintaan yang tinggi terhadap pelayanan yang akan diberikan sesuai dengan tingkat pendidikannya. ${ }^{13}$ Tingkat pendidikan secara tidak langsung juga ikut mempengaruhi karakter berpikir dan bertindak responden terhadap pelayanan, tidak terkecuali pelayanan IFRS..$^{8,12}$

Sedangkan dari jumlah kunjungan pelayanan, sebagian besar responden pernah mengunjungi unit IFRS sebanyak lebih dari 5 kali (48\%). Dalam kaitannya dengan kepuasan pasien, semakin sering responden mendapatkan pelayanan dari fasilitas pemberi layanan, maka penilaian responden akan terhindar dari bias. ${ }^{8}$ Hal ini dikarenakan responden telah mendapatkan gambaran atau pola pelayanan yang diberikan, sehingga responden selanjutnya dapat menilai pelayanan yang telah diberikan.

Dari hasil perhitungan dari seluruh pertanyaan kuesioner, didapatkan bahwa secara umum responden merasa puas akan pelayanan IFRS yang diberikan. Hal ini dapat dilihat pada gambar 1, di mana secara umum responden pada penelitian ini merasa puas dan sangat puas terhadap pelayanan IFRS yang diberikan. Meski demikian, jika ditinjau lebih rinci dari nilai yang diberikan responden pada setiap pertanyaan yang tertera pada kuesioner, terdapat sebagian responden yang merasa tidak puas dan sangat tidak puas pada sebagian aspek kepuasan pasien. Hasil dapat dilihat pada Tabel 2, yang didapatkan dari hasil akumulasi responden yang hanya merasa tidak puas dan sangat tidak puas terhadap sebagian aspek pelayanan IFRS. Dari Tabel tersebut, waktu tunggu pelayanan resep yang lama menjadi salah satu penyebab ketidakpuasan terbesar terhadap pelayanan IFRS Rumah Sakit Universitas Muhammadiyah Malang, dengan 36 orang merasa tidak puas dan 3 orang merasa sangat tidak puas terhadap pelayanan IFRS.

Waktu tunggu pelayanan resep menggambarkan tingkat efisiensi dan efektivitas petugas farmasi dalam pengerjaan resep, serta kesinambungan pelayanan IFRS. ${ }^{3}$ Dari hasil perhitungan rata-rata waktu tunggu pelayanan resep pada Tabel 3, didapatkan rata-rata waktu tunggu pelayanan resep sebesar 29 menit 0 detik pada pelayanan resep obat jadi dan 39 menit 34 detik pada pelayanan resep obat racik. Berdasarkan SPM RS, waktu tunggu disyaratkan tidak lebih dari 30 menit untuk pelayanan resep obat jadi dan 60 menit untuk pelayanan resep obat racik. Dari hasil tersebut, waktu tunggu pelayanan IFRS pada penelitian ini sebenarnya telah memenuhi SPM RS. Namun, terdapat sebagian responden yang memerlukan waktu melebihi standar yang telah ditentukan untuk melakukan pengambilan obat, baik pada pelayanan resep obat racik maupun jadi. Hal ini dapat dilihat pada Tabel 3, di mana 61 dari 150 orang responden (60 orang yang mendapatkan resep obat jadi dan 1 orang yang mendapatkan resep obat racik) memerlukan waktu yang lebih lama untuk melakukan pengambilan obat. Lamanya waktu tunggu pelayanan resep umumnya terjadi pada jam ramai klinik spesialis rawat jalan, yaitu pada pagi hari $(09.00-12.00)$ dan malam hari $(18.00$ $-21.00)$.

Terdapat beberapa faktor yang mempengaruhi lamanya waktu tunggu pelayanan resep. Dari hasil wawancara dengan petugas farmasi pada penelitian ini, kurangnya jumlah petugas farmasi menjadi penyebab lamanya waktu tunggu yang diperlukan oleh responden untuk mengambil obat ditambah dengan beban kerja masing-masing petugas farmasi yang cukup banyak. Peneliti menemui bahwa dalam 1 shift kerja, loket KIE dan penyerahan resep terkadang hanya dilayani oleh 1 orang, dan hal ini terjadi pada jam ramai klinik seperti yang telah dijelaskan sebelumnya. Idealnya satu apoteker melayani 50 resep per hari (rasio 1 apoteker untuk 50 orang pasien rawat jalan). ${ }^{1}$ Meskipun tidak didukung oleh data jumlah resep yang masuk ke pelayanan IFRS, tetapi terjadinya penumpukan berkas BPJS dan kemasan obat mengindikasikan terjadinya kekurangan tenaga kerja farmasi. Selain itu, dari hasil wawancara dengan responden juga ditemukan bahwa petugas farmasi tidak segera memproses berkas BPJS dan kemasan obat. Hal ini ikut menambah waktu tunggu yang diperlukan oleh responden untuk melakukan pengambilan obat. Penumpukan kemasan obat di satu tempat juga akan menghambat kerja petugas farmasi pada bagian yang lainnya.

Pada penelitian ini, analisis korelasional dilakukan dengan 2 metode berbeda dikarenakan adanya perbedaan hasil uji distribusi data antara pelayanan resep obat jadi dan racik. Dari Tabel 4, didapatkan hasil uji distribusi sebesar 0,000 pada pelayanan resep obat jadi dan 0,825 pada pelayanan resep obat racik. Hal ini menunjukkan bahwa data terdistribusi tidak normal pada pelayanan resep obat jadi, sehingga analisis korelasional harus dilakukan dengan metode yang berbeda. Berdasarkan hasil uji distribusi, analisis korelasional dilakukan menggunakan metode Pearson pada pelayanan resep obat racik dan Spearman pada pelayanan resep obat jadi. Kemudian didapatkan nilai p sebesar 0,516 pada pelayanan resep obat racik dan 0,049 pada pelayanan resep obat jadi. Pada pelayanan resep obat jadi di penelitian ini, terdapat hubungan antara waktu tunggu 
pelayanan resep dengan kepuasan pasien. Kekuatan korelasi antara kedua variabel didapatkan sebesar -0,166 pada pelayanan resep obat jadi, di mana hubungan bersifat lemah dan negatif. Dari hasil tersebut, semakin lama waktu tunggu pelayanan resep yang diberikan maka kepuasan pasien akan berkurang. Sebaliknya, pada pelayanan resep obat racik, tidak terdapat hubungan antara waktu tunggu pelayanan resep dengan kepuasan pasien, sehingga juga tidak didapatkan kekuatan korelasi antara kedua variabel.

Berdasarkan hasil wawancara dengan responden, petugas farmasi telah menyampaikan terlebih dahulu kepada responden yang hanya mendapatkan resep obat racik bahwa pengerjaan resep akan memerlukan waktu yang lama, sehingga responden tetap merasa puas terhadap pelayanannya meskipun harus menunggu dalam waktu yang lama untuk melakukan pengambilan obat. Hal ini tidak dilakukan pada pelayanan resep obat jadi, sehingga waktu tunggu pelayanan resep tetap memiliki pengaruh terhadap tingkat kepuasan pasien. Hal ini ikut menyebabkan perbedaan signifikansi antara kedua variabel.

Dari penelitian yang berhubungan dengan waktu tunggu pelayanan resep dan tingkat kepuasan pasien, hasil pada penelitian ini berkebalikan dengan penelitian yang dilakukan oleh Lintang et. al. pada tahun 2017, di mana terdapat hubungan antara waktu tunggu pelayanan resep dengan kepuasan pasien pada pelayanan resep obat racik, tetapi tidak terdapat hubungan antar keduanya pada pelayanan resep obat jadi. ${ }^{9}$ Dari analisis korelasional yang dilakukan menggunakan metode chi-square, didapatkan nilai p sebesar 0,228 pada pelayanan resep obat jadi dan 0,026 pada pelayanan resep obat racik. Secara umum, tidak terdapat hubungan antara kedua variabel pada penelitan tersebut. ${ }^{9}$ Sampai saat ini, belum terdapat penelitian serupa yang terdokumentasikan dan sejalan dengan penelitian ini, sehingga diperlukan referensi penelitian yang baru, khususnya mengenai waktu tunggu pelayanan resep dan kepuasan pasien.

\section{Daftar Pustaka}

1. Kementerian Kesehatan Republik Indonesia. Peraturan Menteri Kesehatan Nomor 58 tahun 2014 tentang Standar Pelayanan Kefarmasian di Rumah Sakit. Kementerian Kesehatan. Jakarta ; 2014.

2. Siregar, Charles J. P. dan Amalia L. Farmasi Rumah Sakit : Teori dan Penerapan. Jakarta : EGC ; 2004.

3. Kementerian Kesehatan Republik Indonesia. Keputusan Menteri Kesehatan NO.129/MENKES/SK/II/2008 tentang Standar Pelayanan Minimal Rumah Sakit. Kementerian Kesehatan. Jakarta ; 2008.

4. Pohan, Imbalo. Jaminan Mutu Layanan Kesehatan : Dasar-dasar Pengertian dan Penerapan. Jakarta : EGC ; 2007.
5. Kementerian Kesehatan Republik Indonesia. Peraturan Menteri Kesehatan Nomor 71 tahun 2013 tentang Pelayanan Kesehatan pada JKN. Kementerian Kesehatan. Jakarta ; 2013.

6. Megawati, Lukman Hakim dan Dolly Irbantoro. Penurunan Waktu Tunggu Pelayanan Obat Rawat Jalan Instalasi Farmasi Rumah Sakit Baptis Batu. Jurnal Kedokteran Brawijaya, 2015; 28 (2): 163-168.

7. Sumartono. Jaminan Mutu Layanan Kesehatan : Dasar-dasar Pengertian dan Penerapan. Jakarta : EGC ; 2007.

8. Aryani, Fina, Husnawati, Septi Muharni, Mutia Liasari, dan Richa Afrianti. Analisa Kepuasan Pasien Rawat Jalan terhadap Kualitas Pelayanan di Instalasi Farmasi Rumah Sakit Islam Ibnu Sina Pekanbaru. PHARMACY, 2015; 12 (1): 101-112.

9. Lintang, Marfilia G., Franckie R.R. Maramis dan Rumayar Adisti A., 2017. Hubungan antara Waktu Tunggu Pelayanan Resep dengan Kepuasan Pasien di Instalasi Farmasi Rumah Sakit Umum Pancaran Kasih GMIM Manado. Public Health Journal, 2017; 9 (3) : $1-8$.

10. Oroh, M. E., S. Rompas, \& L. Pondaag, 2014. Faktorfaktor yang berhubungan dengan tingkat kepuasan pasien rawat inap terhadap pelayanan keperawatan di ruang interna RSUD Noongan. Jurnal Keperawatan, 2 (2).

11. Presiden Republik Indonesia. Undang-Undang Nomor 24 tahun 2011 tentang Badan Penyelenggara Jaminan Sosial. Jakarta ; 2011.

12. Ruditya, Ade Nurma dan Djazuly Chalidyanto, 2015. Hubungan Karakteristik Individu terhadap Penilaian Kualitas Produk Apotek Rawat Jalan. Jurnal Administrasi Kesehatan Indonesia, 2015; 3 (2) : 108 117.

13. Ruditya, D. N., 2014. Faktor yang Berhubungan dengan Kepatuan Penderita Tuberkulosis untuk Memeriksakan Dahak Selama Pengobatan (Studi di Wilayah Kerja Puskesmas Tanah Kalikedinding Kota Surabaya). Skripsi. Surabaya : Universitas Airlangga ; 2014. 